Proc. Estonian Acad. Sci. Eng., 2002, 8, 4, 270-275

\title{
Simultaneity of the wind power in Estonia
}

\author{
Teolan Tomson \\ Estonian Energy Research Institute at Tallinn Technical University, Paldiski mnt. 1, 10137 Tallinn, \\ Estonia; teolan@anet.ee \\ Received 1 February 2002, in revised form 27 March 2002

\begin{abstract}
Analysing synchronous wind speed and power databases at six characteristic sites in West and North Estonia, the simultaneous wind power on the Estonian coastal line is studied. Estonia is big enough not to be covered by the calm totally, but about $33 \%$ of the time wind turbines over the whole Estonia would be performing at an insignificant capacity. The wind energy resource in West Estonia is nearly twice bigger than that in North Estonia due to favourable wind conditions on islands. If wind on islands is not employed (due to environmental restrictions or lack of electrical lines), no big effect can be expected from wind utilization in the rest of the Estonian territory.
\end{abstract}

Key words: wind energy, geographical variation of wind.

\section{INTRODUCTION}

The potential of Estonian wind resource is considered significant $\left[{ }^{1-3}\right]$. In case the economical analysis confirms the feasibility of its usage, a number of wind turbine generators (WTGs) with the total capacity of up to $350 \mathrm{MW}$ could be installed on the coastline. This would allow to generate annually $700 \mathrm{GWh}$ of wind based electricity which would cover about $10 \%$ of the energy consumed in Estonia. The circumstance that the maximums of the wind speed and of the consumed electricity coincide in winter months is highly beneficial. As a disadvantage, the stochastic character of wind must be mentioned; that requires energy storage or at least support from additional hydropower or gas fired power plants. The capacity of additional power generators in the energy system depends on the distribution in time of the total capacity of WTGs in the system, which has not been estimated up to now.

\section{METHOD OF STUDY AND THE DATABASE}

It is not known how to describe a varying in time situation at several dispersed sites with one parameter. The study is based on the resource analysis without considering technical restrictions such as availability of electrical lines, etc. 
The synchronous database of the Estonian Institute of Meteorology and Hydrology for the years 1998-2000 (8760 samplings) is used, based on the data from the meteorological stations at Vilsandi (VLS), Kihnu (KHN), Nigula (NGL), Tallinn-Harku (TLL), Kunda (KND), and Narva (NRV). The first three characterize the wind situation in the western archipelago and on the western coast, the last three on the northern coast. We presume that the WTGs at all sites are the same. The calculations are made in relative units.

The actually measured wind speed data have been multiplied with the constant 1.5 to find an approximate wind speed at the height of 60-70 m (which corresponds to the typical hub height of 1-2 MW WTGs). This coefficient has been established by the approximation of the wind speed shear, according to which the wind speed $u_{2}$ at the height $H_{2}$ depends on the wind speed $u_{1}$ at the height $H_{1}(=10 \mathrm{~m})$ in the following way:

$$
u_{2}=u_{1}\left(H_{2} / H_{1}\right)^{k} \text {. }
$$

Considering recommendations in $\left[{ }^{4}\right]$, we shall take $k=0.23$.

Thus the wind speeds in the present study are only approximate values that have been found without considering the actual location of wind obstacles or landscape roughness class at every site. A more advanced study is expedient only if the preliminary investigation shows feasibility of wind energy utilization, both economically and technically. For the preliminary assessment of energy production, the approximated characteristics and data for WTGs $\left[{ }^{5}\right]$ are used. The 3 -year wind speed database has been transformed into a 3-year database of synchronous wind capacity at the height of 60-70 m.

\section{ANALYSIS OF THE WIND SITUATION}

For the $j$ th WTG, a logical exclusive condition was introduced for the "instant" power $P_{j}^{*}$ based on the threshold value $P_{\mathrm{t}}^{*}$. The threshold value $P_{\mathrm{t}}^{*}$ can be varied, $P_{\mathrm{t}}^{*} \in\{0,0.1,0.5,0.9\}$. The condition $P_{j}^{*} \leq P_{\mathrm{t}}^{*}$ is denoted as " 0 " and the condition $P_{j}^{*}>P_{\mathrm{t}}^{*}$ as " 1 ". For each $P_{\mathrm{t}}^{*}$, a combination of wind power generating conditions can be found (Table 1). The last column of Table 1 shows a fraction in which the denominator means the total number of

Table 1. Coincidence of performance of WTGs at different sites

\begin{tabular}{c|c|c|c|c|c|c}
\hline VLS & KHN & NGL & TLL & KND & NRV & Situation, $s$ \\
\hline 0 & 0 & 0 & 0 & 0 & 0 & $0 / 6$ \\
1 & 0 & 0 & 0 & 0 & 0 & $1 / 6$ \\
1 & 1 & 0 & 0 & 0 & 0 & $2 / 6$ \\
1 & 1 & 1 & 0 & 0 & 0 & $3 / 6$ \\
1 & 1 & 1 & 1 & 0 & 0 & $4 / 6$ \\
1 & 1 & 1 & 1 & 1 & 0 & $5 / 6$ \\
1 & 1 & 1 & 1 & 1 & 1 & $6 / 6$
\end{tabular}


WTGs and the numerator shows the number of WTGs exceeding the threshold. In this estimation, all WTGs are equal and therefore their sequence is not important; for example, situations 101000 and 010001 are both situations 2/6.

Figure 1 shows the result of the wind situation analysis. It can be commented as follows.

1. The condition $P_{\mathrm{t}}^{*}=0$ is the starting condition. When $P_{\mathrm{t}}^{*}=0$ and $s \in\{0 / 6\}$, the probability of such an event $F_{s}$ is $1.9 \%$. Thus all WTGs in Estonia stand idle during $1.9 \%$ of the performance time. All WTGs run (independent from their capacity) according to the condition $\left(P_{\mathrm{t}}^{*}=0, s \in\{6 / 6\}\right)$ during $42.2 \%$ of the performance time. With other performance combinations WTGs remain inside the boundaries $1.9<F_{s}<42.2$.

2. For the condition $P_{\mathrm{t}}^{*}=0.1$ and $s \in\{0 / 6\}$, all the WTGs stand idle or are run with insignificant capacity $0<P_{j}^{*} \leq 0.1$ during $19.8 \%$ of the performance time. For the condition $s \in\{6 / 6\}$ all six WTGs are performing simultaneously, but it is not possible to assess the amount of energy they generate.

3. The condition $P_{\mathrm{t}}^{*}=0.5$ means performance in a low-power range. We can see that during $44.5 \%$ of the performance time no WTG operates in the acceptable power range and only during $1.8 \%$ of the performance time all the six WTGs perform in the accepted range.

4. If $P_{\mathrm{t}}^{*}=0.9$, the capacity of all WTGs exceeds $90 \%$, which means that they perform at their rated power or close to it. Only during $0.3 \%$ of the performance time all six WTGs perform at the rated power, but during $68.6 \%$ of the time no one does it.

Figure 2 shows the time, during which the WTGs at each site and in Estonia in total perform in different ranges of their relative power.

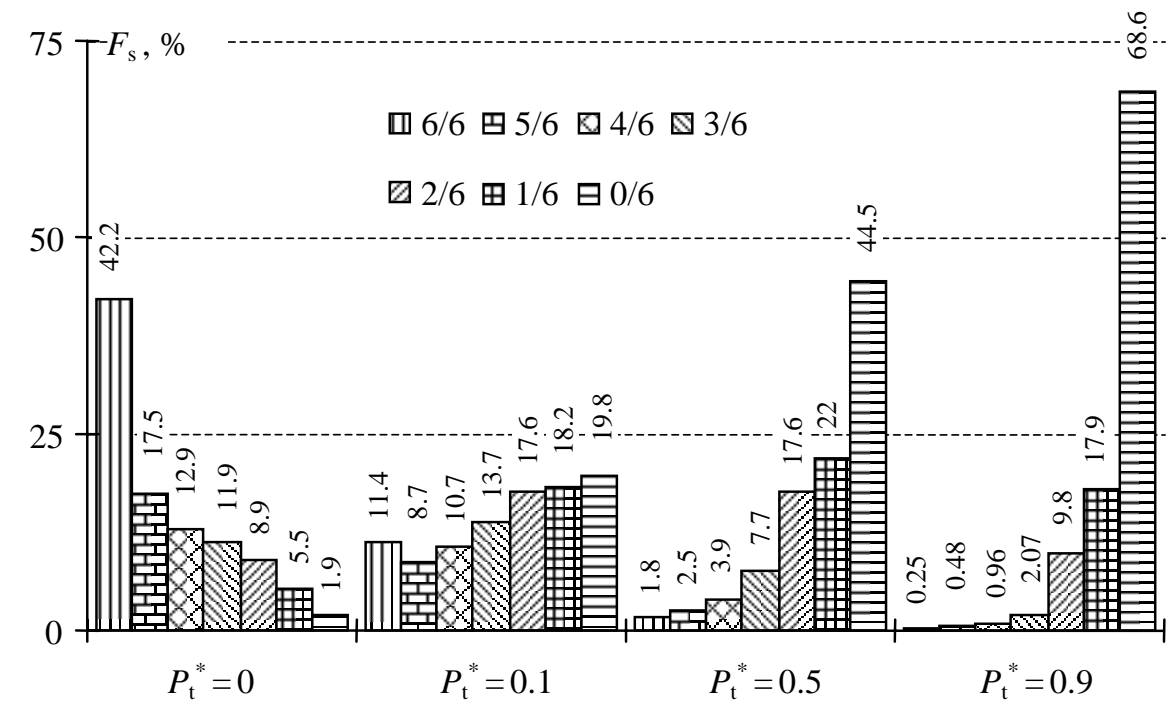

Fig. 1. Probability $F_{s}$ of the synchronous performance of WTGs in Estonia, by different tresholds $P_{\mathrm{t}}^{*}$. 


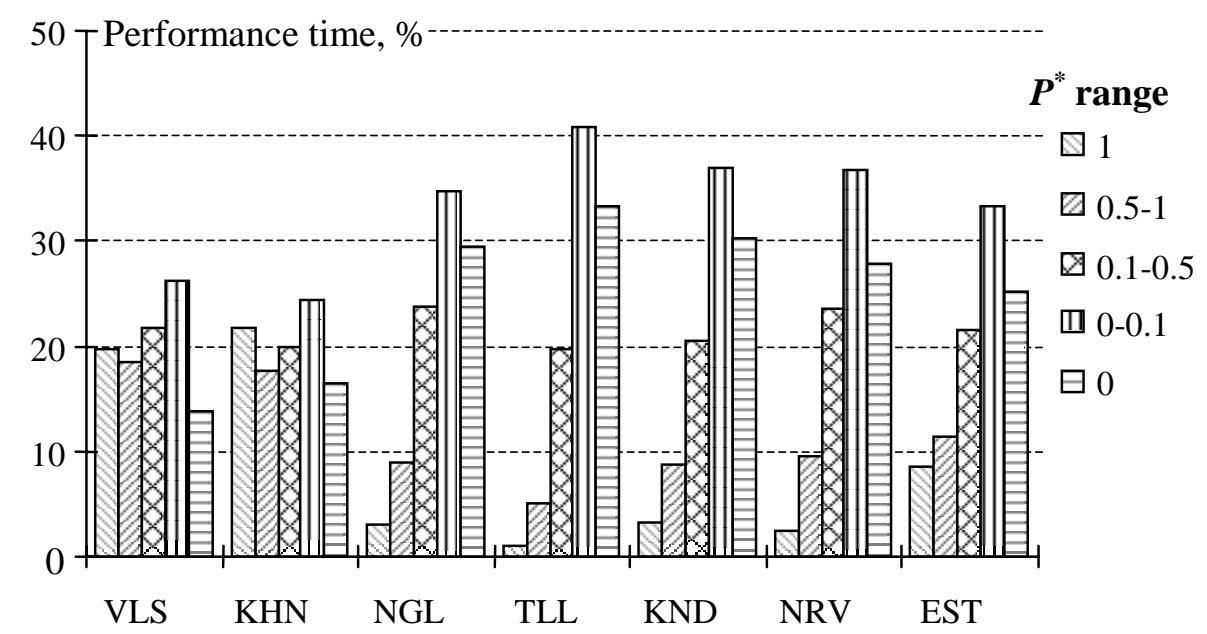

Fig. 2. Relative performance time of the WTGs in different power ranges $P^{*}$ at different sites.

The influence of the distance between WTGs on their performance is of interest. This influence was studied for the pairs VLS $\leftrightarrow$ KHN, KND $\leftrightarrow$ NRV ("the short distance"), NGL $\leftrightarrow$ KND ("the medium distance"), and VLS $\leftrightarrow$ NRV ("the long distance"), shown in Fig. 3. It shows the probability of coincidence $F_{\text {ci }}$, or relative duration of the period when both WTGs in a pair have the same performance range. It has no meaning in this case whether the situation is described by " 0 " or " 1 ". This probability $F_{\text {ci }}$ is high (60-95\%) and there is no significant dependence on the distance between WTGs. The value of $F_{\mathrm{ci}}$ is most stable $\left(72<F_{\mathrm{ci}}<82 \%\right)$ in the pair VLS $\leftrightarrow \mathrm{KHN}$ since it does not significantly depend on the power range. The reason of that may be the "marine" environs of

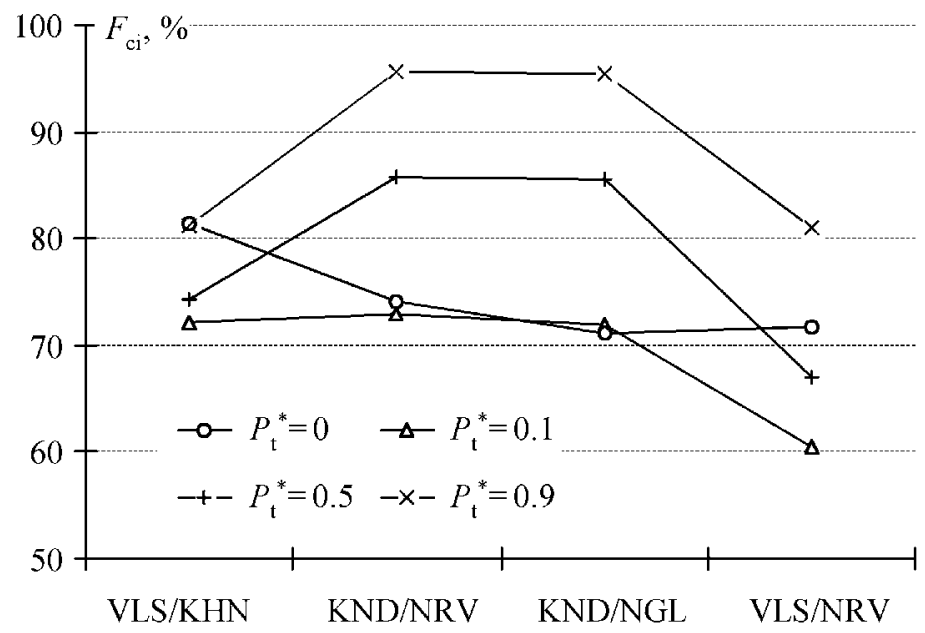

Fig. 3. Coincidence of the power ranges for different pairs of sites. 
both sites rather than short distance between them, since such a coincidence was not observed for the pair $\mathrm{KND} \leftrightarrow \mathrm{NRV}$, where the distance is practically the same.

\section{ADDITIONAL INFORMATION OBTAINED FROM THE DATABASE ON SIMULTANEOUS WIND POWER}

From the database on simultaneous wind power at the height of $60-70 \mathrm{~m}$ additional useful information can be drawn. In Fig. 2, a comparison of the investigated sites is presented from the point of view of energy generation. The following performance ranges are shown for each site: a halted WTG $\left(P^{*}=0\right)$, WTG of insignificant capacity $\left(0<P^{*}<0.1\right)$, WTG of low capacity $\left(0.1<P^{*}<0.5\right)$, WTG of the acceptable capacity $\left(0.5<P^{*}<1\right)$, and WTG with the rated power $\left(P^{*}=1\right)$. In Fig. 4 , the wind power capacity factor $k_{\mathrm{P}}$ is presented for each site, averaged for the regions and for Estonia in total. Best sites are located on islands; most of the sites along the coastal line are in nearly equal conditions (except TLL where conditions for wind energy generation are unfavourable). The annual mean capacity rate of $25 \%$ is satisfactory for Estonia. If we do not exploit wind on islands (due to environmental restrictions or lack of electrical lines), no significant effect can be obtained in wind utilization. Most of the time (33\%, Fig. 2) WTGs in Estonia operate at insignificant load or are halted. The difference of both coastal lines is underlined in Fig. 4.

The present analysis may appear too pessimistic. However, the sites NGL, TLL, and NRV are not located exactly on the coast and it is known $\left[{ }^{6,7}\right]$ that the wind energy increases fast when moving away from the coast. KND is located just at the waterline, but the North Estonian limestone cliff is a large anomalous area involving eddies causing essential decrease of the measured wind speed.

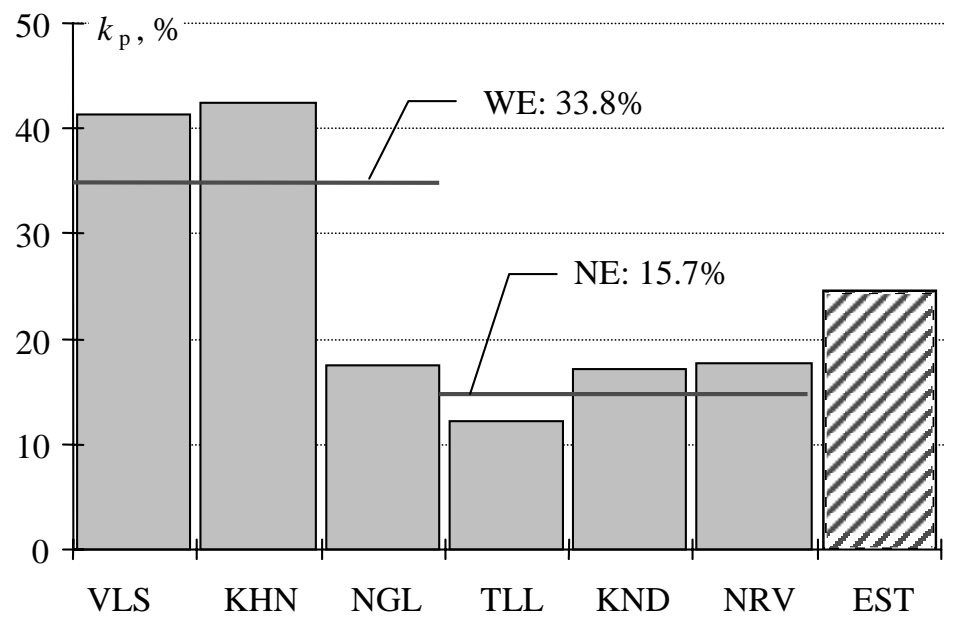

Fig. 4. Wind power capacity at different sites and regions; WE - West Estonia, NE - North Estonia. 


\section{CONCLUSIONS}

1. As it could be expected, Estonia is too small for effective smoothing of wind power fluctuations by distributing wind turbines geographically.

2. At the same time, Estonia is big enough not to be totally involved by a calm or "good wind" condition to cover the whole Estonian territory simultaneously.

3 . Most of the time (33\%) wind turbines in Estonia are insignificantly loaded $\left(P^{*}<10 \%\right)$ or even halted.

4. The western coast with favourable conditions can produce twice more electricity than the northern coast. However, wind turbines operate in the most "synchronized" mode there, i.e., they are working simultaneously in the same relative power range.

5. If we do not employ wind on islands (due to environmental restrictions or lack of electrical lines), no big effect can be expected from wind utilization in the rest of Estonian territory.

\section{REFERENCES}

1. Possible Energy Sector Trends in Estonia. Kallaste, T., Liik, O., and Ots, A. (eds.). SEI Tallinn Centre, Tallinn, 1999.

2. Ots, A., Selg, V., Valma, A., and Kull, A. Situation of wind energy utilization in Estonia. In Proc. European Wind Energy Conference. Nice, 1999, 534-537.

3. TERES II Country Report: Estonia. EC-DGXVII. Energy for Sustainable Development Ltd., Neston, Corsham, UK, 1996.

4. Recent Developments in Wind Power. De Renzo, J. (ed.). Energoatomizdat, Moscow, 1982 (in Russian).

5. Tomson, T. and Hansen, M. Influence of wind speed gusts on the power generation in Estonia. Proc. Estonian Acad. Sci. Eng., 2002, 8, 276-285.

6. Verkaik, J. W. and Tank Klein, A. M. G. Updating the Dutch wind climate assessment. In Proc. European Wind Energy Conference. Nice, 1999, 1045-1047.

7. Nielsen, P., Sorensen, M. V., Sorensen, T., Villadsen, I., and Albinus, L. B. Windatlas Latvia. Preliminary Report, EMD, Aalborg, Denmark, 2001.

\section{Tuule võimsuse kokkulangevusest Eesti territooriumil}

\section{Teolan Tomson}

Kolme iseloomuliku Lääne-Eesti ja kolme Põhja-Eesti paiga sünkroonse tuule kiiruse ja võimsuse andmebaaside analüüsi abil on määratud tuule üheaegse võimsuse ühtlus kogu Eesti rannajoonel. Selgub, et Eesti on küllalt suur selleks, et tuulevaikus ei kataks teda tervikuna. Küll aga 33\% ajast töötaksid tuuleturbiinid kogu Eestis tühise koormusega. Lääne-Eesti tuuleressurss ületab Põhja-Eesti tuuleressursi kahekordselt ja seda eeskätt saarestiku arvel. Kui tuuleenergiat saartel (loodushoiu või elektrivõrgu piirangute tõttu) ei toodeta, on Eesti ülejäänud territooriumil oodata tuuleenergiast vähe efekti. 